\title{
Spatial variations in the frequency-magnitude distribution of earthquakes in the southwestern Okinawa Trough
}

\author{
Jing-Yi Lin ${ }^{1,4}$, Jean-Claude Sibuet ${ }^{1}$, Chao-Shing Lee ${ }^{2}$, Shu-Kun Hsu ${ }^{3}$, and Frauke Klingelhoefer ${ }^{1}$ \\ ${ }^{1}$ Ifremer, Centre de Brest, B.P. 70, 29280 Plouzané, France \\ ${ }^{2}$ Institute of Applied Geophysics, National Taiwan Ocean University, 2 Pei-Ning Road, Keelung 202, Taiwan \\ ${ }^{3}$ Institute of Geophysics, National Central University, Chung-Li 32001, Taiwan \\ ${ }^{4}$ Collège de France, Chaire de Géodynamique, Europôle de l'Arbois, Bat. Le Trocadéro - Aile Sud, BP 80, 13545 Aix en Provence cedex 4, France
}

(Received August 9, 2006; Revised December 5, 2006; Accepted December 26, 2006; Online published May 7, 2007)

\begin{abstract}
The relations between the frequency of occurrence and the magnitude of earthquakes are established in the southern Okinawa Trough for 2823 relocated earthquakes recorded during a passive ocean bottom seismometer experiment. Three high $b$-values areas are identified: (1) for an area offshore of the Ilan Plain, south of the andesitic Kueishantao Island from a depth of $50 \mathrm{~km}$ to the surface, thereby confirming the subduction component of the island andesites; (2) for a body lying along the $123.3^{\circ} \mathrm{E}$ meridian at depths ranging from 0 to $50 \mathrm{~km}$ that may reflect the high temperature inflow rising up from a slab tear; (3) for a third cylindrical body about $15 \mathrm{~km}$ in diameter beneath the Cross Backarc Volcanic Trail, at depths ranging from 0 to $15 \mathrm{~km}$. This anomaly might be related to the presence of a magma chamber at the base of the crust already evidenced by tomographic and geochemical results. The high $b$-values are generally linked to magmatic and geothermal activities, although most of the seismicity is linked to normal faulting processes in the southern Okinawa Trough.
\end{abstract}

Key words: $b$-Values, southern Okinawa Trough backarc basin, slab tear, magma chamber.

\section{Introduction}

Located east of Taiwan, the southern Okinawa Trough (OT) is a portion of a young continental backarc basin that is at the end of the rifting stage (Sibuet et al., 1998) (Fig. 1(a)). Normal faulting is a common tensional process evidenced by seismic reflection data (Sibuet et al., 1998) and focal mechanism analyses (Fournier et al., 2001; Kao and Jian, 2001; Kubo and Fukuyama, 2003). In the southern OT, the volcanic front of the Ryukyu subduction zone is located within the backarc basin (Sibuet et al., 1998; Wang et al., 2000) (Fig. 1(a)). The most obvious cluster of seamounts, which consists of more than 70 volcanoes, is located in the vicinity of $24.8^{\circ} \mathrm{N} ; 122.8^{\circ} \mathrm{E}$ and is named the "Crossbackarc volcanic trail" (CBVT) (Sibuet et al., 1998; upperleft inset in Fig. 1(a)). Based on the relocated hypocenter locations (Engdahl et al., 1998), magnetic anomaly distributions (Hsu et al., 2001) and depths of the magnetic basement (Lin et al., 2004a), a slab tear has been identified along the $123.3^{\circ} \mathrm{E}$ meridian (Fig. 1(a)). However, despite the microseismicity in the southern Okinawa Trough being very high, the surrounding land stations are too distant to record this stab tear. Consequently, with the objective of gaining a better understanding of the nature and role of tectonic features in this region, we conducted a passive seismic ocean bottom seismometer (OBS) experiment in November 2003.

Ishimoto and Ida (1939) and Gutenberg and Richter (1944) introduced the relation between the frequency of oc-

Copyright (c) The Society of Geomagnetism and Earth, Planetary and Space Sciences (SGEPSS); The Seismological Society of Japan; The Volcanological Society of Japan; The Geodetic Society of Japan; The Japanese Society for Planetary Sciences; TERRAPUB. currence and the magnitude of earthquakes. The commonly used form is $\log _{10} N=a-b M$, where $N$ is the cumulative number of earthquakes with a magnitude equal or larger than $M$, and $a$ and $b$ are constants. The parameter ' $b$ ' is the slope of the best fitting line between the observed number of earthquakes at a given magnitude and the magnitude (e.g. Fig. 2(d)). Since its first formulation, many studies of the frequency-magnitude distribution (FMD) as a function of time and space have been performed. For example, volcanic areas are commonly associated with high $b$-values (Warren and Latham, 1970), and underlying magma chambers are also characterized by anomalously high $b$-values (Wiemer and Wyss, 1997; Wiemer et al., 1998; Murru et al., 1999). The $b$-value has been shown to be inversely proportional to stress in laboratory (Scholz, 1968) and in mines experiments (Urbancic et al., 1992). Stress and indirectly confining pressure are parameters which strongly control the type of faults and $b$-values.

For example, normal faulting events (tensional stress) have systematically the highest $b$-values and thrust events (compressional stress) have systematically the lowest (Frohlich and Davis, 1993; Wiemer and Wyss, 1997; Schorlemmer et al., 2005). The presence of melt and normal faults that induce the distribution of high $b$-values are both present in the southern OT (e.g. Sibuet et al., 1998; Shinjo, 2003a, b). We have calculated the spatial distribution of $b$-values in order to gain an understanding of how these may account for this complex tectonic regime and compare these results with a $V p / V s$ ratio and $P$ - and $S$-velocity tomographic inversion performed with the same earthquakes (Lin et al., 2006a, accepted). 


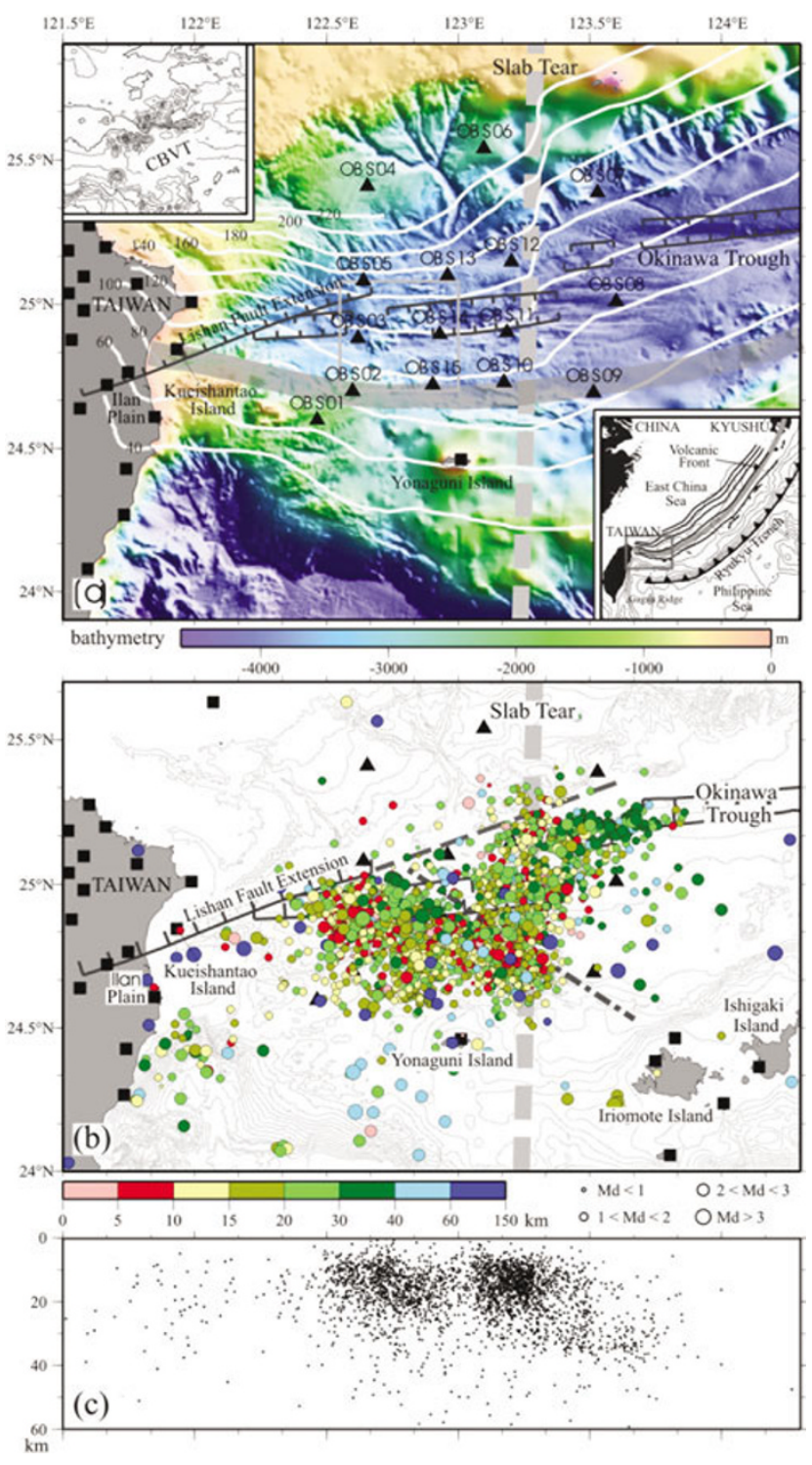

Fig. 1. (a) Map showing the simplified tectonic framework of the southern Okinawa Trough (OT). The locations of the Ryukyu trench and Okinawa Trough normal faults are from Sibuet and Hsu (2004). Upper-left corner inset: detailed bathymetric map (isobathic spacing, $100 \mathrm{~m}$ ) of the cross-backarc volcanic trail (CBVT) (Sibuet et al., 1998) located in the southern OT. The white contour lines are depths of the Wadati-Benioff zone (adapted from Font et al. (1999)). (b) Hypocenters of $2823 \mathrm{mi}-$ croearthquakes relocated with the SIMUL2000 program in the southwestern OT during the 12-days acquisition period (Lin et al., 2006b, revised). The size of dots is function of the magnitude. Colors show the depth ranges, with bathymetric contours every $100 \mathrm{~m}$. The dashed line is the prolongation of the Lishan fault. Black triangles correspond to the locations of OBS stations, and black squares to surrounding land stations. The gray-colored dashed line shows the location of the slab tear. The large gray-colored line shows the location of the volcanic front. (c) E-W vertical cross section of the hypocenter distribution.

\section{Data and Method}

Fifteen OBSs were deployed in the southern OT from November 19 to December 1, 2003. More than $3300 \mathrm{mi}-$ croearthquakes were recorded during this 12-days passive seismic experiment (Fig. 1(b); Lin et al., 2006b, revised). All $P$ - and $S$ - arrival times were picked by hand. As the amplitudes of the seismograms recorded by the OBS instruments were not calibrated, the magnitudes of the earth- quakes were evaluated using the duration of seismic waves (Md) of other measurements (e.g. $\mathrm{M}_{\mathrm{L}}, \mathrm{Md}$, Ms and Mw). The duration of each event was determined manually. The magnitudes of most of the earthquakes $(\mathrm{Md})$ range from 1 to 2, although the whole range consists of magnitudes from 0.9 to 4 (Fig. 1(b)). This range in magnitude, dominated by small-magnitude earthquakes, provides an appropriate dataset to calculate $b$-values because the use of smallmagnitude earthquakes increases the precision of $b$-values estimation (Wiemer and Wyss, 2002). In order to obtain accurately locate the hypocenters, all of the earthquakes were relocated using the SIMUL2000 program (Thurber and Eberhart-Phillips, 1999). The layered model from the best VELEST solution was used (Kissling et al., 1994) as the starting one-dimensional (1-D) model, and a minimal grid spacing of $15 \mathrm{~km}$ is used for the SIMUL2000 program. Following the tomographic inversion, a detailed 3-D velocity model was obtained (Lin et al., 2006a, accepted), and all of the earthquakes were relocated using this 3-D velocity model. Only hypocenters determined at an accuracy lower than $10 \mathrm{~km}$ in the three directions were chosen for the FMD calculations. In total, 2823 earthquakes were relocated. After relocation, the average rms residual decreases from 0.242 to $0.151 \mathrm{~s}$, showing a better determination of hypocenters. Wiemer and Wyss (2002) have demonstrated that using earthquakes of different magnitudes (e.g. $\mathrm{M}_{\mathrm{L}}$, $\mathrm{Md}$, Ms and Mw) may induce systematic errors. To avoid this problem, we only used the Md magnitude determined from the OBS stations, even if the available magnitude of the same earthquakes was calculated separately from the Taiwanese and Japanese networks.

Several areas with a $V p / V s$ higher than 1.78 are can be determined based on the tomographic results (Lin et al., 2006a, accepted). Since the presence of melt or $\mathrm{H}_{2} \mathrm{O}$ enriched material is characterized by low $V p$, low $V s$ and high $V p / V s$ (Watanabe, 1993; Reyner et al., 2006), we have highlighted such areas on Fig. 2(b) in white dashed contours. These high $V p / V s$ anomalies rise obliquely from a depth of $50 \mathrm{~km}$ through the slab tear in three directions (Fig. 3): a first branch rises northwesterly and feeds the CBVT; a second branch rises in a northerly direction above the slab tear to a depth of $15 \mathrm{~km}$; a third branch rises to the north of Irimote Island $\left(24.5^{\circ} \mathrm{N} ; 123.9^{\circ} \mathrm{E}\right)$. The resolution estimates for the tomographic inversion are relatively high $(>0.6)$ in the central part of the southern OT at a shallow depth $(5-\mathrm{km})$. For the deeper part, the resolution decreases, but it is still acceptable beneath the Ryukyu Arc (>0.5).

Zmap software (Wiemer, 2001; Wiemer and Wyss, 1994, 1997 ) is used to estimate $b$-values at the nodal points of a 2-D grid using the 50 nearest earthquakes. The shape of the sampling volume is a vertical cylinder, and the grid spacing is $0.05^{\circ}$. The height of each sampling cylinder is $5 \mathrm{~km}$, and the center of the cylinder corresponds to the depth of each estimated layer. The high-density hypocenter distribution allows us to use a grid spacing as small as $5 \mathrm{~km}$ in order to increase the spatial resolution. The resolution map corresponds to the radii of each circle of sampling (Fig. 2(c)): the larger the radius, the lower the chance of analyzing small sub-volumes. The magnitude of completeness $(M c)$ is a factor used to calculate the $b$ - and $a$-values, which should 


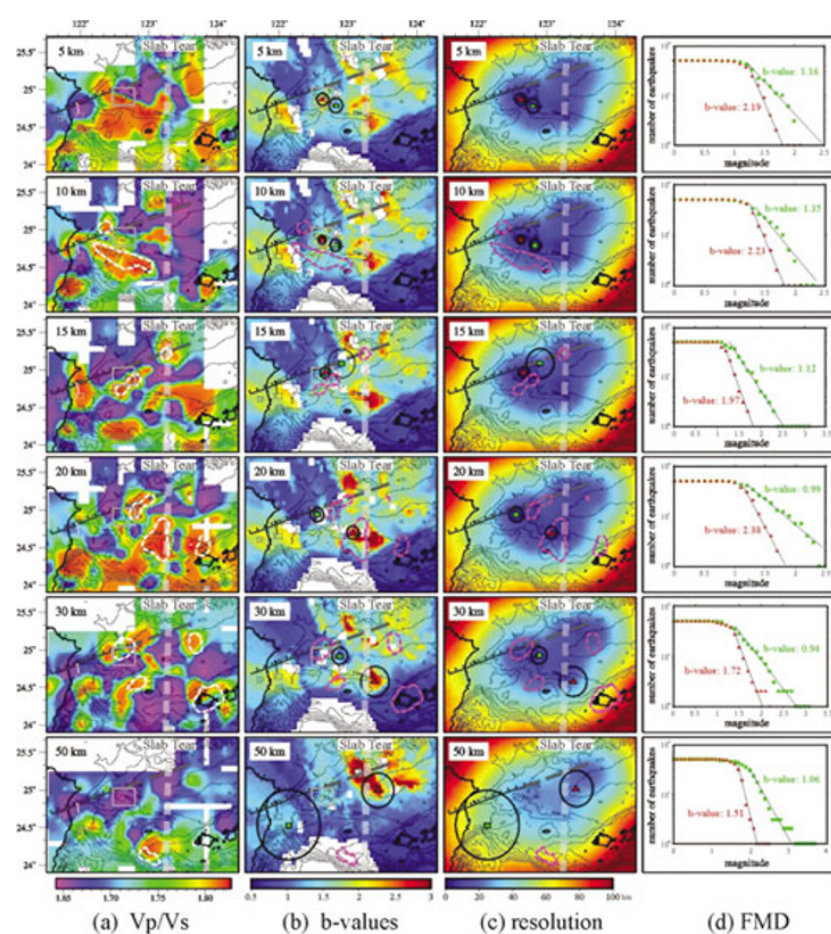

Fig. 2. (a) $V p / V s$ distribution in the southern OT displayed for six slices from 5 to $50 \mathrm{~km}$. White dashed contours show areas where high $V p / V s$ and low $V p, V s$ velocities are observed on the tomographic results (Lin et al., 2006a, accepted). The black dashed line shows the prolongation of Lishan fault. The light-colored dashed line shows the position of the slab tear. The light-gray square indicates the cross-backarc volcanic trail (CBVT). KI: Kueishantao Island. IP: Ilan Plain; (b) $b$-values distribution. The two circles with a red triangle and a green square in their centers define the volumes for which the frequency-magnitude relations are shown in (d). (c) Distribution of spatial resolution. Red, dashed contours shows the areas where high $V p / V s$ and low $V p, V s$ velocities are observed. (d) Comparison of frequency magnitude distribution (FMD) for the two circles located in (b) and (c). Black, straight lines show the best fitting lines whose slope is the $b$ value.

correspond to the maximum value of the FMD derivative for each sample. Instead of assuming a unique $M c$ value, $M c$ is automatically calculated according to the FMD in each sample. The suited $M c$ value used for each sample under investigation allows us to correct $b$ - and $a$-values estimations. The $b$-values estimations are finally obtained by using both maximum likelihood (Aki, 1965; Bender, 1983) and the weighted least squares methods. In this case, the results are independent of the method (Bender, 1983).

\section{Results and Discussion}

The 3-D mapping of $b$-values in the southern OT shows that within the crust the background $b$-value is approximately 1.1 , with three embedded volumes characterized by $b>2.0$ (Fig. 2(b)). One of these major anomalies is located offshore the Ilan Plain, south of Kueishantao Island, at depths ranging from 0 to $50 \mathrm{~km}$. The feeding process of the volcanic Kueishantao Island with melt and/or $\mathrm{H}_{2} \mathrm{O}$ enriched material rising from the Ryukyu slab edge has already been established from a previous tomographic study using earthquakes recorded by the Taiwanese network (Lin et al., 2004b). We suggest that the high $b$-values correspond to the feeding channels imaged by tomographic results,

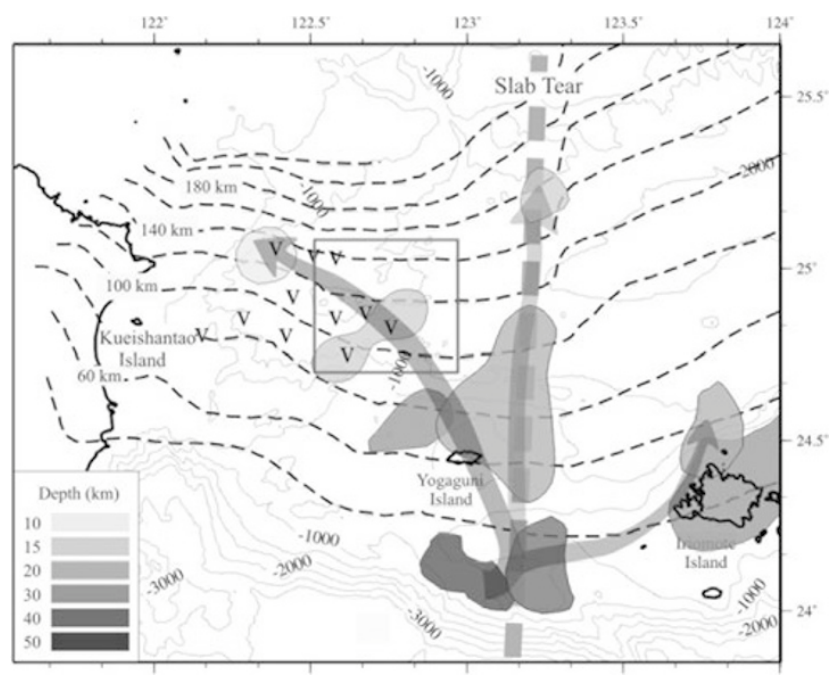

Fig. 3. Geophysical distribution of areas with $V p / V s$ values higher than 1.78 and low $V p$ and low $V s$ values, extracted from slices of Figs. 6-8 and ranging from $10 \mathrm{~km}$ (light gray) to $50 \mathrm{~km}$ (dark gray) (Lin et al., 2006a, accepted). Dashed lines are the isobaths of the Wadati-Benioff zone (adapted from Font et al. (1999)). Light-colored arrows show the upward propagation trends. $\mathrm{V}$ are the locations of detected hot vents (Lee, 2005). The black square indicates the cross-backarc volcanic trail (CBVT).

which rises up from a depth of $50 \mathrm{~km}$ to the surface in the direction of Kueishantao Island (Lin et al., 2004b). However, the $\sim 40 \mathrm{~km}$ spatial resolution in this area (Fig. 2(c)) does not allow us to discuss this correspondence in more detail.

The most prominent anomaly in $b$-values corresponds to a volume of relatively high $b$-values located above the $\mathrm{N}$ $\mathrm{S}$ trending slab tear in the vicinity of the $123.3^{\circ} \mathrm{E}$ meridian (Fig. 2(b)). This anomaly in high $b$-values $(>2.3)$ is imaged at depths ranging from 0 to $50 \mathrm{~km}$ (Fig. 2(b)). At a depth of $50 \mathrm{~km}$, part of this anomaly deviates eastward of the slab tear beneath the northern slope of OT. Glasby and Notsu (2003) reported the presence of a high heat potential along this N-S trending slab tear area. As mentioned previously, magmas and hot fluids in geothermal systems may induce high $b$-values (Wiemer and Wyss, 2002). We suggest that the high temperature of the inflowing mantle through the slab tear and the wedge may provide a high geothermal potential in this area. The anomalous heat originating from the slab tear may be transmitted to the overlying crust. In addition, such a heat transfer may also follow a magma conduit. This point will be discussed in the following section.

A vertical cylindrical body with high $b$-values, about 15 $\mathrm{km}$ in diameter, occurs at a shallow depth $(015 \mathrm{~km})$ beneath the CBVT (light-gray square, Fig. 2(a), (b)). The FMDs inside (red triangles) and outside (green squares) of this vertical cylinder show a large difference in $b$-values $(\sim 2$ and $\sim 1$, respectively; see slices from 5 to $15 \mathrm{~km}$ in Fig. 2(d)), emphasizing the fact that $b$-values beneath volcanoes are generally smaller than previously thought and are distributed in pockets of anomalously high $b$-values embedded in a crust characterized by a mean $b$-value of $\sim 1$ (e.g. Wiemer and Wyss, 2002; Power et al., 1998; Murru et al., 1999). According to the tomographic results, the low $V p$, low $V s$ and 
and high $V p / V s$ anomalies at depths between 10 and 15 $\mathrm{km}$ suggest the existence of a magma chamber located beneath the CBVT area (Figs. 2(a) and 3) (Lin et al., 2006a, accepted). Earthquakes are not generated within the magma chambers but around it. We thus interpreted the envelope of high $b$-values anomalies beneath the CBVT as the contours of the magma chambers. The mapped anomaly of $b$-values actually does include both the surrounding parts of magma chambers and the magma conduits to the surface (Fig. 3); however, it is located in the upper crust $(0-10 \mathrm{~km})$ and may also be linked to the presence of geothermal systems, as evidenced by tremor sources located in this area (Chang et al., 2006, submitted) and by the distribution of hot vents in the southern OT (Lee, 2005; Chang et al., 2006, submitted).

High $V p / V s$ and low $V p, V s$ anomalies have been identified in the southern OT (dashed contours in Fig. 2(a)-(c); Lin et al., 2006a, accepted) and linked to the presence of melt and/or fluid-enriched material. At depths of less than $20 \mathrm{~km}$, the distribution of the high $b$-values corresponds to the volumes surrounding the high $V p / V s$ and low $V p, V s$ anomalies. At larger depths $(>30 \mathrm{~km})$, the correlation between high $b$-values and high $V p / V s$ anomaly disappears. As mentioned in several former studies, stress is an important factor that affects the distribution of the $b$-values (Scholz, 1968; Wyss, 1973; Shaw, 1995) and may explain this discrepancy. Based on tomographic images, three subchannels corresponding to melt and/or $\mathrm{H}_{2} \mathrm{O}$-enriched material rising from the slab tear have been identified (Lin et al., 2006a, accepted). Two of the three conduits reach the upper crust of the southern OT (Fig. 3): one rises towards the northwest in the direction of the CVBT to a depth of 10 $\mathrm{km}$ where a magma chamber has been suggested from geochemical analyses of dredged rocks (Shinjo et al., 2003a, b); the second rises to the north along the slab tear in the direction of the northern OT slope, to a depth of $15 \mathrm{~km}$. The anomalies of high $b$-values mapped in our study at a shallow depth $(<30 \mathrm{~km})$ are in good agreement with the position of the two chambers. Hence, this comparison gives more credit to the fact that magmatic and/or geothermal activities might be the main factors controlling the distributions of high $b$-values. In addition, most of the anomalies of high $b$-values anomalies are not systematically located in the axial part of the southern OT, where numerous E-W trending normal faults account for the present-day extension in the OT (Sibuet et al., 1998). High $b$-values underline features of volcanic or geothermal origin rather than the presence of numerous normal faults.

\section{Conclusion}

The distribution of small-magnitude earthquakes has been established from a passive seismic experiment in the southwestern OT. $b$-values were computed by using 2823 relocated earthquakes selected from this earthquakes dataset. Three volumes of high $b$-values were identified: (1) a first body characterized by $b \sim 2$ is located offshore of the Ilan Plain, south of Kueishantao Island, and rises from the edge of the slab at a depth of $50 \mathrm{~km}$ to the surface, thereby confirming that the andesitic nature of rocks presents a subduction component (Chen et al., 1995); (2) a second anomaly lies along the $123.3^{\circ} \mathrm{E}$ meridian, at depths ranging from 0 to $50 \mathrm{~km}$, above the Ryukyu slab tear, suggesting that high $b$-values are related to this feature; High temperature inflow passing through the slab tear might affect the overlying mantle and crust, and the heat anomaly might accelerate the generation of hot fluid in the geothermal system, resulting in high $b$-values; (3) a third body with a cylinder shape of about $15 \mathrm{~km}$ in diameter is identified beneath the CBVT, at depths ranging from 0 to $15 \mathrm{~km}$; This anomaly is related to a magma chamber located at the base of the crust $(10-15 \mathrm{~km})$, as already suggested both by the tomographic results and the geochemical interpretation of dredged rocks. Though the seismicity in the southern OT is mainly controlled by normal faulting, high $b$-values are linked to volcanic and geothermal activities.

Acknowledgments. The Ifremer OBS group and the captain and crew of the $R / V$ Ocean Research $I$ are acknowledged for their help during the cruise. The Zmap software was used to compute $b$ values (Wiemer, 2001) and the GMT software package to draw the figures (Wessel and Smith, 1991). This work is part of an ongoing cooperative project between France and Taiwan encouraged and supported by Ifremer, the Institut Français de Taipei and by the National Science Council of Taiwan. Pertinent discussions with Wen-Nan Wu are acknowledged.

\section{References}

Aki, K., Maximum likelihood estimate of $\mathrm{b}$ in the formula $\log \mathrm{N}=\mathrm{a}-\mathrm{bM}$ and its confidence limits, Bull. Earthq. Res. Inst., Tokyo Univ., 43, 237-239, 1965.

Bender, B., Maximum likelihood estimation of $b$-values for magnitude grouped data, Bull. Seismol. Soc. Am., 73, 831-851, 1983.

Chang, T.-Y., J.-C. Sibuet, C.-S. Lee, and J.-Y. Lin, Tremors in the Southwestern Okinawa Trough., Tectonophysics, 2006 (submitted).

Chen, C. H., T. Lee, Y. N. Hsieh, C.-H. Chen, and W. Y. Hsu, Magmatism at the onset of back arc basin spreading in Okinawa Trough, J. Volcanol. Geotherm. Res., 69, 313-322, 1995.

Engdahl, E. R., R. D. Van der Hilst, and R. P. Buland, Global teleseismic earthquake relocation with improved travel times and procedures for depth determination, Bull. Seismol. Soc. Am., 88, 722-743, 1998.

Font, Y., S. Lallemand, and J. Angelier, Etude de la transition entre l'orogène actif de Taiwan et la subduction des Ryukyu-Apport de la sismicité, Bull. Soc. Géol. Fr., 170, 271-283, 1999.

Fournier, M., O. Fabbri, J. Angelier, and J.-P. Cadet, Regional seismicity and on-land deformation in the Ryukyu Arc: Implications for the kinematics of opening of the Okinawa Trough, J. Geophys. Res., 106, 13,751-13,768, 2001

Frohlich, C. and S. Davis, Teleseismic b values: Or, much ado about 1.0, J. Geophys. Res., 98, 631-644, 1993.

Glasby, G. P. and K. Notsu, Submarine hydrothermal mineralization in the Okinawa Trough, SW Japan: an overview, Ore. Geol. Rev., 23 (3-4), 299-339, 2003.

Gutenberg, R. and C. F. Richter, Frequency of earthquakes in California, Bull. Seismol. Soc. Am., 34, 185-188, 1944.

Hsu, S.-K., J.-C. Sibuet, and C.-T. Shyu, Magnetic inversion of the East China Sea and Okinawa Trough: Tectonic implications, Tectonophysics, 333, 111-122, 2001.

Ishimoto, M. and K. Iida, Observations of earthquakes registered with the microseismograph constructed recently, Bull. Earthq. Res. Inst., 17, 443-478, 1939.

Kao, H. and P.-R. Jian, Seismogenic patterns in the Taiwan region: Insights from source parameter inversion of BATS data, Tectonophysics, 333, 179-198, 2001.

Kissling, E., W. L. Ellsworth, D. Eberhart-Phillips, and U. Kradolfer. Initial reference models in local earthquake tomography, J. Geophys. Res., 99, 19635-19646, 1994.

Kubo, A. and E. Fukuyama, Stress field along the Okinawa Trough and the Ryukyu Arc inferred from moment tensors of shallow earthquakes, Earth Planet. Sci. Lett., 210, 305-316, 2003.

Lee, Y. L., The study of active submarine volcanoes and hydrothermal vents in the southernmost part of Okinawa Trough, Master thesis, National Taiwan Ocean University, Taiwan, 45 pp, 2005 (in Chinese). 
Lin, J.-Y., S.-K. Hsu, and J.-C. Sibuet, Melting features along the Ryukyu slab tear, beneath the southwestern Okinawa Trough, Geophys. Res. Lett., 31, L19607, doi:10.1029/2004GL020862, 2004a.

Lin, J.-Y., S.-K. Hsu, and J.-C. Sibuet, Melting features along the western Ryukyu slab edge (northeast Taiwan): Tomographic evidence, J. Geophys. Res., 109, B12402, doi:10.1029/2004JB003260, 2004 b.

Lin, J.-Y., J.-C. Sibuet, C. S. Lee, S.-K. Hsu, and F. Klingelhoefer, Origin of the southern Okinawa Trough volcanism from detailed seismic tomography, J. Geophys. Res., 2006a (accepted).

Lin, J.-Y., J.-C. Sibuet, C. S. Lee, S.-K. Hsu, F. Klingelhoefer, Y. Auffret, P. Pelleau, and J. Crozon. Microseisismicity and faulting in the southwestern Okinawa Trough, Tectonophysics, $2006 \mathrm{~b}$ (revised).

Murru, M., C. Montuori, M. Wyss, and E. Privitera, The location of magma chambers at Mt. Etna, Italy, mapped by b-values, Geophys. Res. Lett., 26, 2553-2556, 1999.

Power, J. A., M. Wyss, and J. L. Latchman, Spatial variations in frequency-magnitude distribution of earthquakes at Soufrière Hills volcano, Montserrat, West Indies, Geophys. Res. Lett., 25, 3653-3656, 1998.

Reyners, M., D. Eberhart-Phillips, G. Stuart, and Y. Nishimura, Imaging subduction from the trench to $300 \mathrm{~km}$ depth beneath the central North Island, New Zealand, with Vp and Vp/Vs, Geophys. J. Int., 165(2), 565$583,2006$.

Scholz, C. H., The frequency-magnitude relation of microfracturing in rock and its relation to earthquakes, Bull. Seismol. Soc. Am., 58, 399415, 1968.

Schorlemmer, D., S. Wiemer, and M. Wyss, Wariations in earthquakesize distribution across different stress regimes, Nature, 437, doi:10.1038/nature04094, 2005.

Shaw, B. E., Frictional weakening and slip complexity in earthquake faults, J. Geophys. Res., 100, 18,239-18,252, 1995.

Shinjo, R., S. Hokakubo, S. Haraguchi, T. Matsumoto, and J. Woodhead, Geochemical characteristics of volcanic rocks from the southern Okinawa Trough and its implications for tectono-magmatic evolution, EOS Trans. AGU, 84(46), Fall Meet. Suppl., Abstract V31E-0973, 2003a.

Shinjo, R., S. Hokakubo, S. Haraguchi, and T. Matsumoto, Regional variation in geochemistry of volcanic rocks from the southern Okinawa Trough, Earth Mon., 43, 21-26, 2003 b (in Japanese).

Sibuet, J.-C., B. Deffontaines, S.-K. Hsu, N. Thareau, J.-P. Le Formal, and C.-S. Liu, The southwestern Okinawa Trough back-arc basin: Tectonics and volcanism., J. Geophys. Res., 103, 30,245-30,267, 1998.

Sibuet, J.-C. and S.-K. Hsu, How was Taiwan created?, Tectonophysics, 379, 159-181, 2004.

Thurber, C. H. and D. Eberhart-Phillips, Local earthquake tomography with flexible gridding, Comput. Geosci., 25, 809-818, 1999.

Urbancic, T. I., C. I. Trifu, J. M. Long, and R. P. Toung, Space-time correlations of $b$-values with stress release, PAGEOPH, 139, 449-462, 1992.

Wang, C., M.-L. Yang, C.-P. Chou, Y.-C. Chang, and C.-S. Lee, Westward extension of the Okinawa Trough and its western end in the northern Taiwan area: Bathymetric and seismological evidence, Terr. Atm. Oc. Sci., 372, 167-177, 2000.

Warren, N. W. and G. V. Latham, An experimental study of thermally induced microfracturing and its relation to volcanic seismicity, J. Geophys. Res., 75, 4455-4464, 1970.

Watanabe, T., Effects of water and melt on seismic velocities and their application to characterization of seismic reflectors, Geophys. Res. Lett., 20, 2933-2936, 1993.

Wessel, P. and W. M. F. Smith, Free software helps map and display data, EOS Trans. Am. Geophys. Union, 72, 441-446, 1991.

Wiemer, S., A software package to analyze seismicity: ZMAP, Seismol. Res. Lett., 72, 373-382, 2001.

Wiemer, S. and M. Wyss, Seismic quiescence before the $1993 \mathrm{M}=7.5$ Landers and $\mathrm{M}=6.5 \mathrm{Big}$ Bear (California) earthquakes, Bull. Seismol. Soc. Am., 84, 900-916, 1994.

Wiemer, S. and M. Wyss, Mapping the frequency-magnitude distribution in asperities: An improved technique to calculate recurrence times?, $J$. Geophys. Res., 102, 15,115-15,128, 1997.

Wiemer, S. and M. Wyss, Mapping spatial variability of the frequencymagnitude distribution of earthquakes, Adv. Geophys., 45, 259-302, 2002.

Wiemer, S., S. R. McNutt, and M. Wyss, Temporal and three-dimensional spatial analysis of the frequency-magnitude distribution near Long Valley caldera, California, Geophys. J. Int., 134, 409-421, 1998.

Wyss, M., Towards a physical understanding of the earthquake frequency distribution, Geophys. J. R. Astr. Soc., 31, 341-359, 1973.

J.-Y. Lin (e-mail: jylin@ifremer.fr, lin@cdf.u-3mrs.fr), J.-C. Sibuet, C.S. Lee, S.-K. Hsu, and F. Klingelhoefer 